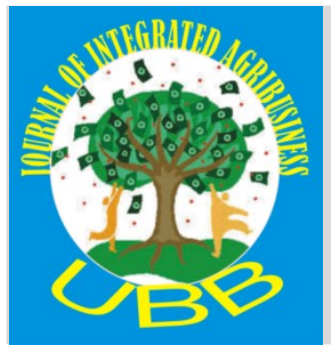

\title{
Journal of Integrated Agribusiness
}

\author{
Website Jurnal: http://journal.ubb.ac.id/index.php/jia \\ P-ISSN: 2656-3835 E-ISSN: 2686-2956
}

\section{COMPARATIVE STUDY ON FARMER INCOME IN RELOCATED AND UNRELOCATED VILLAGES}

\section{PERBANDINGAN PENDAPATAN PETANI DI DESA YANG DIRELOKASI DAN TIDAK DIRELOKASI}

\author{
Cyntia Dwi Permataa, Diana Chalilb*, Emalisac, Riantri Barus ${ }^{d}$ \\ $\mathrm{a}, \mathrm{b}, \mathrm{c}, \mathrm{d}$ Program Studi Agribisnis, Fakultas Pertanian, Universitas Sumatera Utara, Medan, Indonesia \\ * Email Korespondensi: diana3@usu.ac.id
}

Dikirim: 20 Mei 2020, Diterima: 24 Juli 2020, Diterbitkan, 31 Juli 2020

\begin{abstract}
The purpose of this study is to compare farmers' income in the relocated and unrelocated villages. Data were collected from 30 samples from each relocated and unrelocated villages, using purposive sampling approach and analyzed with a compare means independent sample t-test. The result shows significant difference between the farmers' income of relocated and unrelocated villages. This stems from the different composition of cultivated commodities, productivities and selling prices of the commodities. The formers are related to the soil condition, while the latter to the transportation and accessibility.
\end{abstract}

Keywords: Income; Relocated; Not Relocated; Different Independent Sample T-Test

\begin{abstract}
Abstrak
Tujuan penelitian ini adalah untuk menganalisis perbandingan pendapatan petani di desa yang direlokasi dengan yang tidak direlokasi. Data diperoleh dari 30 petani di desa yang direlokasi dan 30 dari desa yang tidak direlokasi yang ditentukan dengan metode purposive sampling. Selanjutnya data dianalisis dengan uji beda rata-rata (independent sample t-test). Hasil penelitian menunjukkan bahwa pendapatan petani di desa yang di relokasi lebih rendah dibandingkan dengan pendapatan petani di desa yang tidak direlokasi. Penyebabnya adalah pemilihan komposisi jenis komoditi, produktivitas dan harga jual dari masing masing komoditi. Hal tersebut terkait dengan kondisi lahan, sarana transportasi dan aksesbilitas.
\end{abstract}

Kata kunci: Pendapatan; Relokasi; Tidak Relokasi; Uji Beda Rata-Rata 


\section{PENDAHULUAN}

Sejak terjadi letusan Gunung Sinabung pada tahun 2010 Kecamatan Naman Teran merupakan salah satu kecamatan yang terkena dampak letusan Gunung Sinabung, mengakibatkan Desa Bekerah dan Desa Simacem di kecamatan tersebut tidak dapat lagi berfungsi baik sebagai lahan pertanian dan harus direlokasi ke Desa Siosar yang terletak di kawasan hutan produksi, Kecamatan Merek, Kabupaten Karo. Petani yang direlokasi mendapat fasilitas tempat tinggal dan lahan seluas 0,5 ha per KK. Tujuannya adalah untuk menjamin kehidupan yang layak kepada korban erupsi Gunung Sinabung. Namun luas tersebut relatif lebih kecil dibandingkan dengan rata-rata luas lahan petani/KK pada saat sebelum direlokasi yaitu sebesar 3,9 Ha/KK (Badan Pusat Statistik Kabupaten Karo, 2018). Kondisi tanahnya juga tidak begitu gembur serta teksturnya yang padat dan kering, cuaca yang ekstrim dengan angin kencang dan kemarau berkepanjangan. Hal tersebut dapat menyebabkan turunnya pendapatan petani di daerah yang direlokasi dapat menurun dibandingkan dengan pendapatan sebelum direlokasi. Penelitian ini dilakukan untuk menguji hipotesis tersebut.

\section{METODOLOGI PENELITIAN}

\subsection{Pemilihan Daerah Penelitian}

Penelitian dilakukan di Kecamatan Naman Teran, Kabupaten Karo, yang merupakan kecamatan yang terkena dampak erupsi Gunung Sinabung sehingga menyebabkan adanya desa yang direlokasi.

\subsection{Penentuan Populasi Dan Sampel}

Populasi dalam penelitian ini adalah petani yang berada di desa yang direlokasi dan di desa yang tidak direlokasi. Sampel ditentukan dengan metode purposive sampling, dengan jumlah sampel dari desa yang direlokasi dan dari desa yang tidak direlokasi masing-masing sebanyak 30 orang.

\subsection{Pengumpulan Data}

Data dalam penelitian ini terdiri dari data primer dan data sekunder. Data primer adalah data yang diperoleh melalui wawancara dan pengamatan langsung, mencakup data karakteristik petani, data penggunaan input produksi serta biayanya, data komposisi komoditi yang ditanamam petani, data jumlah produksi dan harga jual produk. Sementara data sekunder adalah data dari Kantor Kepala Desa dan Dinas Pertanian Kabupaten Karo.

\subsection{Metode Analisis Data}

Pendapatan usahatani dihitung dengan menggunakan rumus:

$$
\mathbf{I}=\mathbf{T R}-\mathbf{T C}
$$

Dimana I = Income (Pendapatan Usahatani) $(\mathrm{Rp} / 14$ Bulan), TR = Total Revenue (Total Penerimaan) (Rp/14 Bulan) dan TC = Total Cost (Total Biaya) (Rp/14 Bulan)

Pendapatan dihitung berdasarkan nilai riil (tanpa memperhitungkan pengeluaran biaya tenaga kerja dalam keluarga). Periode produksi dihitung dalam 14 bulan untuk mencakup periode seluruh jenis komoditi yang diusahakan baik pada desa yang direlokasi maupun 
tidak. Biaya total merupakan penjumlahan semua biaya yang dikeluarkan petani dalam melakukan usahatani untuk semua komoditi yang diusahakan dalam periode 14 bulan. Biaya yang dikeluarkan petani mencakup biaya bibit, biaya pupuk, biaya pestisida, biaya tenaga kerja, biaya penyusutan peralatan dan biaya lain-lainnya.

$\mathrm{TC}=\mathrm{TFC}_{\mathrm{j}}+\Sigma \mathbf{X}_{\mathrm{i}} \cdot \mathbf{P x _ { \mathrm { i } }}$

Dimana TFC $=$ Total Fixed Cost (Total Biaya Tetap), yang dihitung dengan total biaya penyusutan pada alat $\mathrm{j}$. Untuk desa yang direlokasi alat $\mathrm{j}$ terdiri dari $1=$ cangkul, $2=$ pompa, 3 = parang, 4 = gilingan kopi, sedangkan untuk desa yang tidak direlokasi alat $\mathrm{j}$ terdiri dari 1 = cangkul, $2=$ mesin pompa, $3=$ pompa, $4=$ selang, $5=$ drum, dan $6=$ parang; $X_{i}=$ kuantitas penggunaan input ke $i$; Pxi = harga per unit input ke $i$, input $i$ terdiri dari $1=$ Bibit, $2=$ pupuk, $3=$ pestisida, $4=$ tenaga kerja, dan $5=$ lainnya.

Besarnya penerimaan usahatani dapat dihitung dengan rumus:

$$
T R=\sum_{i=1}^{n} Y i . P y i
$$

Dimana $Y_{i}=$ kuantitas penjualan komoditi ke i $(\mathrm{Kg})$, Pyi = harga jual rata-rata per $\mathrm{kg}$ komoditi ke i, dimana i terdiri dari $1=$ kentang, $2=$ kubis, $3=$ jagung, $4=$ ubi jalar, $5=$ cabai merah keriting, $6=$ kopi untuk desa yang direlokasi, dan $1=$ ketang, $2=$ kubis, $3=$ cabai merah keriting, $4=$ cabai hijau, $5=$ petsai, $6=$ tomat untuk desa yang tidak direlokasi.

Seluruh perhitungan biaya, penerimaan dan pendapatan dilakukan dengan dua pendekatan yaitu (1) per hektar dan (2) per petani. Perhitungan per ha bertujuan untuk menganalisis optimalisasi penggunaan lahan, sedangkan per petani untuk menganalisis tingkat kesejahteraan keluarga petani.

Perbedaan pendapatan petani yang direlokasi dan tidak direlokasi digunakan uji dianalisis dengan menggunkan independent sample t-test.

$$
t=\frac{\overline{x_{1}}-\overline{x_{2}}}{\sqrt{\frac{\left(n_{1}-1\right) S_{1}^{2}+\left(n_{2}-1\right) S_{2}^{2}}{n_{1}+n_{2}-2}\left\langle\frac{1}{n_{1}}+\frac{1}{n_{2}}\right\rangle}}
$$

dimana $\bar{X}_{1}=$ rata-rata data kelompok 1 (desa yang direlokasi), $\bar{X}_{2}=$ rata-rata data kelompok 2 (desa yang tidak direlokasi), $S_{1}{ }^{2}=$ standar deviasi kelompok $1, S_{2}{ }^{2}=$ standar deviasi kelompok 2, $n_{1}=$ jumlah sampel kelompok $1, n_{2}=$ Jumlah sampel kelompok 2 Dengan kriteria pengujian: $\mathrm{H}_{0}$ diterima jika: $t_{\text {hitung }} \leq t_{\text {tabel }}$ atau Sig. $>0,05$ dan $\mathrm{H}_{1}$ diterima jika : $t_{\text {hitung }}>t_{\text {tabel }}$ atau Sig. $\leq 0,05$. 


\section{HASIL DAN PEMBAHASAN}

\subsection{Komposisi Penggunaan Lahan di Desa yang Direlokasi dengan Desa yang Tidak Direlokasi}

Dari hasi penelitian, dapat dilihat bahwa komposisi penggunaan lahan di desa yang direlokasi dengan di desa yang tidak direlokasi berbeda seperti yang dapat dilihat pada Gambar 1 dan 2. Ada jenis tanaman yang sama tetapi ada juga jenis tanaman yang berbeda. Tanaman yang sama-sama diusahakan yaitu kentang, kubis, dan cabai merah keriting di desa yang direlokasi lebih rendah dibandingkan dengan desa yang tidak direlokasi.

Berikut dapat dilihat perbedaan komposisi penggunaan lahan di desa yang direlokasi dengan desa yang tidak direlokasi untuk setiap komoditinya.

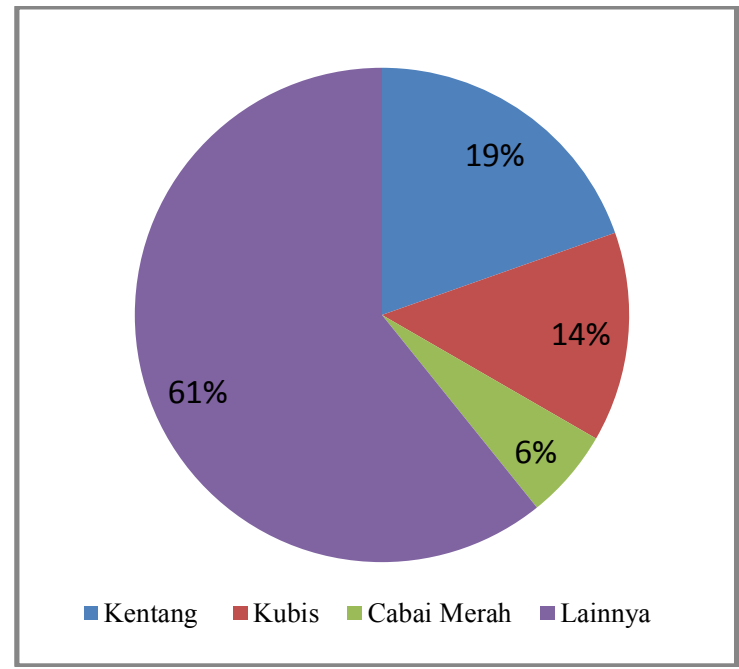

Gambar 1. Komposisi Penggunan Lahan di Desa yang Direlokasi

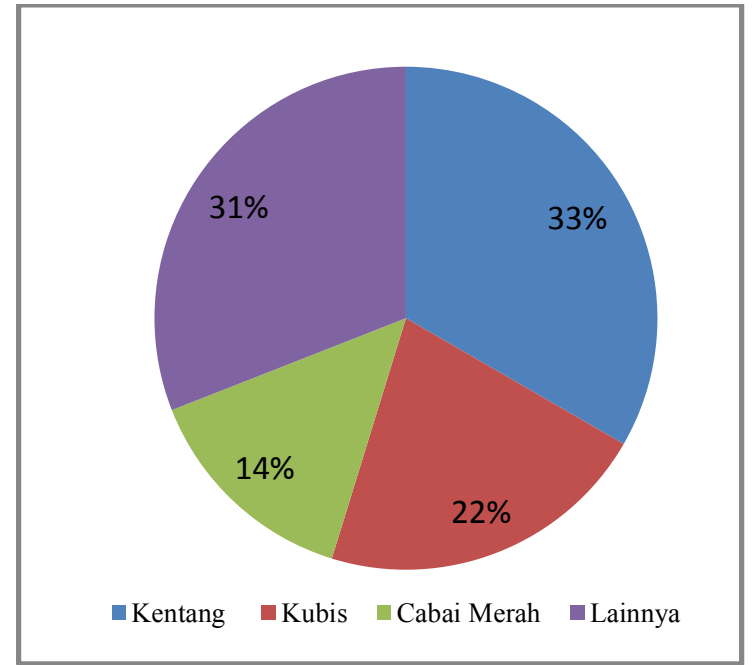

Gambar 2. Komposisi Penggunaan Lahan di Desa yang Tidak Direlokasi

Penggunaan lahan untuk komoditi lainnya (ubi jalar, jagung, dan kopi) lebih besar di desa yang direlokasi yaitu 61\%. Petani banyak menanam ubi jalar karena ubi jalar termasuk komoditi yang tidak sensitif baik terhadap hama maupun keadaan iklim sehingga perawatannya tidak rumit, namun kelemahannya adalah harga komoditi ubi jalar yang rendah yaitu Rp.2.000/kg dan hanya dapat dipanen satu kali musim tanam saja dengan umur produksi 4-5 bulan. Begitu juga dengan tanaman jagung, tanaman jagung juga memiliki harga yang rendah yaitu dengan harga Rp.3000/kg, Berbeda dengan kopi, yang memiliki harga tinggi yaitu Rp.29.375/kg.

Di desa yang tidak direlokasi, penggunaan lahan untuk komoditi lainnya (petsai, cabai hijau dan tomat) lebih rendah yaitu hanya 31\% dari luas lahan seluruhnya. Tomat merupakan komoditi yang dapat dipanen berkali kali dengan umur masa produksi 3 bulan dengan harga Rp.4.591/kg. Begitu juga dengan cabai hijau dapat di panen berkali kali dengan umur masa produksi 3 bulan dengan harga Rp.26.000/kg. dan petsai merupakan tanaman yang hanya dapat di panen satukali musim tanam dengan umur produksi 3 bulan dengan harga Rp.1.950/kg. Berikut harga masing- masing komoditi di desa yang direlokasi dengan desa yang tidak direlokasi. 
Tabel 1: Harga Masing-Masing Komoditi per Kg

\begin{tabular}{|c|c|c|c|}
\hline \multirow[b]{2}{*}{ No } & \multirow[b]{2}{*}{ Uraian } & \multicolumn{2}{|c|}{ Harga/Kg } \\
\hline & & Desa Yang Direlokasi & $\begin{array}{c}\text { Desa Yang Tidak } \\
\text { Direlokasi }\end{array}$ \\
\hline & Komoditi yang sama & & \\
\hline 1 & Kentang & 5.356 & 6.000 \\
\hline 2 & Kubis & 2.358 & 2.344 \\
\hline 3 & $\begin{array}{l}\text { Cabai Merah Kriting } \\
\text { Komoditi Lainnya }\end{array}$ & 43.750 & 43.800 \\
\hline 1 & Ubi Jalar & 2.000 & - \\
\hline 2 & Jagung & 3.000 & - \\
\hline 3 & Kopi & 29.375 & - \\
\hline 4 & Petsai & - & 1.950 \\
\hline 5 & Cabai Hijau & - & 26.000 \\
\hline 6 & Tomat & - & 4.591 \\
\hline
\end{tabular}

3.2. Produktivitas Komoditi di Desa yang Direlokasi dan di Desa yang Tidak Direlokasi

Dari Tabel 2 dapat dilihat bahwa produktivitas tanaman kentang di desa yang direlokasi dengan desa yang tidak direlokasi berbeda dengan selisih $12.101 \mathrm{~kg} / \mathrm{ha} / 14$ bulan, terutama akibat perbedaan bibit yang digunakan serta keadaan tanah. Di desa yang direlokasi petani menggunakan bibit kentang generasi lama yaitu hasil produksi dari tanaman kentang yang didapat dari pemerintah pada akhir tahun 2015 sebagian di jadikan bibit kembali, sehingga umbi kentang yang dihasilkan tidak begitu besar dan produktivitas dan penerimaan. Alasan petani tidak menggunakan benih kentang yang baru karena keterbatasan modal.

Lain halnya di desa yang tidak direlokasi, petani menggunakan bibit generasi baru yang mereka beli di penangkaran bibit kentang yang ada di sekitar desa sehingga umbi kentang yang dihasilkan berukuran besar dan produktivitas kentang yang dihasilkan juga tinggi.

Selain bibit yang berbeda perbedaan kodisi tanah juga diduga menyebabkan perbedaan produktivitas usahatani di desa yang direlokasi dengan desa yang tidak direlokasi. Di desa yang direlokasi, keadaan tanah sangat kering akibat curah hujan yang rendah yaitu $2000 \mathrm{~mm} /$ tahun, sehinga membuat tanaman kentang tidak dapat tumbuh secara optimal. Berbeda dengan keadaan tanah yang di desa yang tidak di relokasi kondisi tanah tidak terlalu kering.

Tabel 2: Rata-Rata Hasil Produksi dan Produktivitas Petani Sampel

\begin{tabular}{|c|c|c|c|c|c|}
\hline \multirow{2}{*}{$\begin{array}{c}\mathbf{N} \\
\mathbf{0}\end{array}$} & \multirow{2}{*}{ Uraian } & \multicolumn{2}{|c|}{ Desa Yang Direlokasi } & \multicolumn{2}{|c|}{$\begin{array}{c}\text { Desa Yang Tidak } \\
\text { Direlokasi }\end{array}$} \\
\hline & & $\begin{array}{l}\mathrm{Kg} / \text { Petani } \\
/ 14 \text { Bulan }\end{array}$ & $\begin{array}{l}\mathrm{Kg} / \mathrm{Ha} / \\
14 \text { Bulan }\end{array}$ & $\begin{array}{l}\mathrm{Kg} / \text { Petani } \\
\text { /14 Bulan }\end{array}$ & $\begin{array}{l}\mathrm{Kg} / \mathrm{Ha} / \\
14 \text { Bulan }\end{array}$ \\
\hline & Komoditi Yang Sama & & & & \\
\hline 1 & Kentang & 5.628 & 11.256 & 10.167 & 23.357 \\
\hline 2 & Kubis & 6.258 & 12.517 & 12.611 & 24.147 \\
\hline 3 & Cabai Merah Kriting & 1.300 & 2.600 & 3.647 & 9.456 \\
\hline
\end{tabular}




\begin{tabular}{|c|c|c|c|c|c|}
\hline \multirow{2}{*}{$\begin{array}{l}\mathbf{N} \\
\mathbf{o}\end{array}$} & \multirow{2}{*}{ Uraian } & \multicolumn{2}{|c|}{ Desa Yang Direlokasi } & \multicolumn{2}{|c|}{$\begin{array}{c}\text { Desa Yang Tidak } \\
\text { Direlokasi }\end{array}$} \\
\hline & & $\begin{array}{l}\mathrm{Kg} / \text { Petani } \\
/ 14 \text { Bulan }\end{array}$ & $\begin{array}{l}\mathrm{Kg} / \mathrm{Ha} / \\
14 \text { Bulan } \\
\end{array}$ & $\begin{array}{l}\text { Kg/Petani } \\
\text { /14 Bulan }\end{array}$ & $\begin{array}{l}\mathrm{Kg} / \mathrm{Ha} / \\
14 \text { Bulan } \\
\end{array}$ \\
\hline & Komoditi Lainnya & & & & \\
\hline 1 & Ubi Jalar & 11.120 & 22.240 & - & - \\
\hline 2 & Jagung & 4.383 & 8.767 & - & - \\
\hline 3 & Kopi & 411 & 821 & - & - \\
\hline 4 & Petsai & - & - & 11.000 & 28.046 \\
\hline 5 & Cabai Hijau & - & - & 2.867 & 9.549 \\
\hline 6 & Tomat & - & & 8.883 & 22.003 \\
\hline
\end{tabular}

Produktivitas tanaman cabai merah kriting di desa yang direlokasi dengan desa yang tidak direlokasi juga berbeda jauh dengan selisih $6.946 \mathrm{~kg} / \mathrm{ha} / 14$ bulan. Dari pengamatan yang dilakukan saat penelitian salah satu penyebab perbedaan yaitu karena keadaan tanah yang kering tanaman tumbuh kerdil dengan daun kriting, dan ketika tanaman masih muda sudah terserang penyakit sehingga tidak dapat di jual. Sampai saat ini petani masih belum mengetahui secara pasti penyebab penyakit-penyakit tersebut. Kendala petani dalam memecahkan masalah ini karena penyuluh yang bertugas di desa ini tidak aktif sehingga menyulitkan petani untuk berdiskusi dengan pihak Dinas Pertanian yang mereka anggap sangat besar perannya dalam memecahkan masalahmasalah yang dihadapi dalam usahatani.

\subsection{Biaya Produksi, Penerimaan dan Pendapatan di Desa yang Direlokasi dan di Desa yang tidak Direlokasi}

Total biaya yang dikeluarkan petani di desa yang direlokasi lebih rendah dibandingkan desa yang tidak di relokasi, dengan selisih Rp.39.330.580/ha/14 bulan. Rata-rata biaya yang dikeluarkan petani berdasarkan jenis biaya yang dikeluarkan dapat dilihat pada Tabel 3 .

Tabel 3: Rata-rata Jumlah Biaya Produksi Petani Sampel

\begin{tabular}{|c|c|c|c|c|c|c|c|}
\hline \multirow[b]{2}{*}{$\begin{array}{l}\mathbf{N} \\
\mathbf{o}\end{array}$} & \multirow[b]{2}{*}{ Jenis Biaya } & \multicolumn{3}{|c|}{ Desa yang Direlokasi } & \multicolumn{3}{|c|}{ Desa yang tidak Direlokasi } \\
\hline & & $\begin{array}{c}\text { Rp/Petan } \\
\text { i/14 } \\
\text { Bulan } \\
\end{array}$ & $\begin{array}{c}\mathrm{Rp} / \mathrm{Ha} / \\
14 \text { Bulan }\end{array}$ & $(\%)$ & $\begin{array}{c}\text { Rp/Petan } \\
\text { i/14 } \\
\text { Bulan } \\
\end{array}$ & $\begin{array}{c}\mathrm{Rp} / \mathrm{Ha} / \\
14 \text { Bulan }\end{array}$ & $(\%)$ \\
\hline 1 & Bibit & 889.267 & 1.778 .533 & 4,8 & 5.849 .933 & 13.543 .673 & 17,6 \\
\hline 2 & Pupuk & 6.483 .400 & 12.966 .800 & 34,8 & 7.616 .600 & 19.248.294 & 25,1 \\
\hline 3 & Pestisida & 2.732 .200 & 5.464 .400 & 14,7 & 4.205 .433 & 10.404 .339 & 13,5 \\
\hline 4 & Tenaga Kerja & 6.930 .000 & 13.860 .000 & 37,2 & 10.916 .000 & 27.285 .621 & 35,6 \\
\hline 5 & Penyusutan & 238.763 & 477.526 & 1,3 & 336.109 & 823.305 & 1,1 \\
\hline 6 & $\begin{array}{l}\text { Alat } \\
\text { Biava Lain-lain }\end{array}$ & 1.353 .000 & 2.706 .000 & 7,3 & 2.143.267 & 5.278 .608 & 6,9 \\
\hline
\end{tabular}

Dari Tabel 3, diketahui dari semua jenis biaya yang dikeluarkan petani terdapat perbedaan antara petani yang direlokasi dengan petani yang tidak direlokasi. Perbedaan biaya yang paling besar berasal dari biaya tenaga kerja dengan selisih 
Rp.13.425.621/ha/14 bulan. Di desa yang direlokasi lebih sedikit menggunakan tenaga kerja luar keluarga di bandingkan dengan desa yang tidak direlokasi, sehingga membuat pengeluaran untuk biaya tenaga kerja tinggi. Rata-rata upah tenaga kerja di desa yang direlokasi dan tidak direlokasi hampir sama, yaitu sekitar Rp.12.000/jam (Rp.70.000/hari dengan 6 jam kerja di desa yang direlokasi dan Rp.60.000/hari dengan 5 jam kerja di desa yang tidak direlokasi).

Biaya bibit yang digunakan di desa relokasi lebih sedikit dibandingkan biaya bibit di desa yang tidak direlokasi dengan selisih sebesar Rp.11.765.140/ha/14 bulan karena di desa yang direlokasi bibit yang digunakan adalah dari tanaman sebelumnya yang merupakan pemberian Pemerintah, sedangkan di desa yang tidak direlokasi menggunakan bibit generasi baru yang di beli dari penangkaran bibit kentang dengan harga Rp.20.000-Rp.22.000/kg. Di samping itu di desa yang direlokasi untuk tanaman ubi jalar petani tidak mengeluarkan biaya bibit yang tinggi karena berasal dari tunas tanaman ubi petani lain yang sudah menanam tanaman ubi terlebih dahulu.

Seperti yang sudah dijelaskan pada bagian sebelumnya, perbedaan jenis komoditi yang ditanam dengan harga jual yang berbeda menyebabkan perbedaan penerimaan. Rata-rata penerimaan petani berdasarkan komoditi dapat dilihat pada Tabel 4.

Dari Tabel 4. dapat dilihat bahwa komoditi di desa yang direlokasi dengan desa yang tidak direlokasi tidak semuanya sama. Komoditi yang sama hanya komoditi kentang, kubis dan cabai merah keriting. Komoditi yang berbeda yaitu, di desa yang direlokasi terdapat komoditi ubi jalar, jagung, dan kopi. Di desa yang tidak direlokasi terdapat komoditi petsai, cabai hijau dan tomat. Berikut total rata-rata penerimaan petani dari berbagi komoditi yang ditanam.

Tabel 4: Rata-Rata Penerimaan Petani dari masing-masing Komoditi

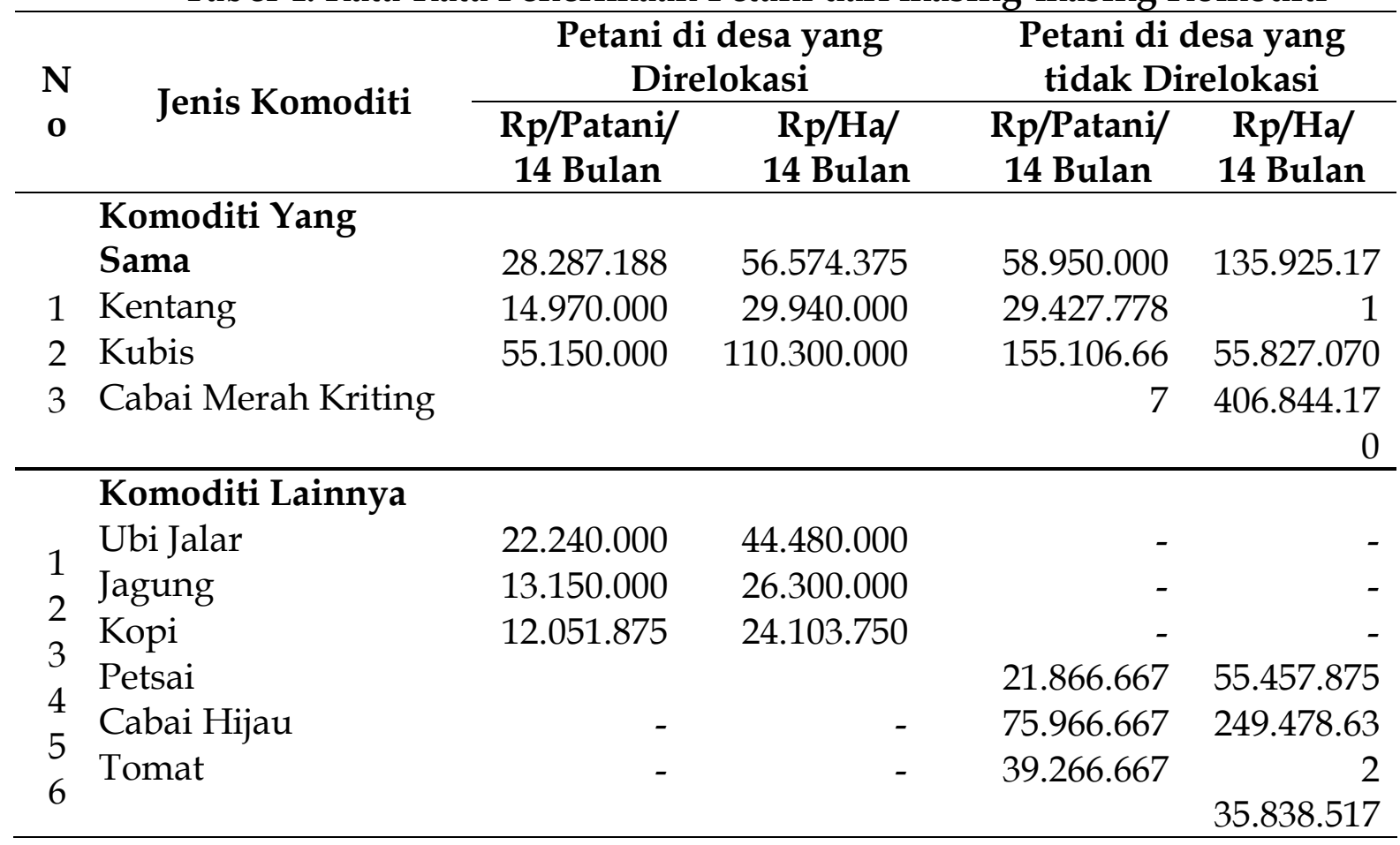


Rata-rata pendapatan per petani dan per ha dapat dilihat pada Tabel 5. Dari Tabel 5 dapat dilihat rata-rata pendapatan per petani di desa yang direlokasi lebih rendah dibandingkan desa yang tidak direlokasi. Rata-rata pendapatan per petani di desa yang direlokasi sebesar Rp.33.685.537/14 bulan atau Rp.2.406.095/bulan, sedangkan di desa yang tidak direlokasi sebesar Rp.110.279.325/14 bulan atau Rp.7.877.095/bulan. Jika dikaitkan dengan UMK Karo sebesar Rp.2.829.558/bulan, maka pendapatan rata-rata petani di desa yang direlokasi masih di bawah UMK sedangkan pendapatan rata-rata petani di desa yang tidak direlokasi sangat jauh di atas UMK Karo.

Tabel 5: Rata-rata Pendapatan per Petani dan per Hektar per 14 Bulan

\begin{tabular}{|c|c|c|c|c|}
\hline \multirow[t]{2}{*}{ No } & \multicolumn{2}{|l|}{ Uraian } & $\begin{array}{l}\text { Desa Yang } \\
\text { Direlokasi }\end{array}$ & $\begin{array}{c}\text { Desa Yang Tidak } \\
\text { Direlokasi }\end{array}$ \\
\hline & \multicolumn{2}{|c|}{ Luas Lahan Usahatani- (Ha) } & 0,5 & 0,42 \\
\hline \multirow{3}{*}{1} & \multirow{3}{*}{$\begin{array}{l}\text { Pendapatan Per Petani } \\
\text { Per } 14 \text { Bulan }\end{array}$} & Penerimaan & 52.312 .167 & 141.364 .667 \\
\hline & & Biaya & 18.626 .630 & 31.067 .342 \\
\hline & & Pendapatan & 33.685 .537 & 110.279.325 \\
\hline \multirow{3}{*}{2} & \multirow{3}{*}{$\begin{array}{l}\text { Pendapatan Per Ha Per } \\
14 \text { Bulan }\end{array}$} & Penerimaan & 104.624 .333 & 357.622 .854 \\
\hline & & Biaya & 37.253 .260 & 76.583 .840 \\
\hline & & Pendapatan & 67.371.074 & 281.039.013 \\
\hline
\end{tabular}

Pendapatan petani di desa yang tidak direlokasi lebih tinggi dibandingkan dengan petani yang direlokasi. Setidaknya terdapat 2 penyebab yaitu (1) untuk komoditi yang sama, harga yang diterima petani di desa yang tidak direlokasi lebih tinggi. (2) Selain itu, petani di desa yang tidak direlokasi juga menanam komoditi lain, dengan harga jual yang relatif tinggi. Misalnya cabai hijau yang harganya bisa mencapai Rp.26.000/kg, yang tidak ditanam oleh petani yang direlokasi. Akibatnya, penerimaan petani di desa yang direlokasi lebih rendah dibandingkan desa yang tidak direlokasi dengan selisih sebesar Rp. 252.998.521/ha/14 bulan.

Hasil uji beda rata-rata menunjukkan perbedaan yang signifikan antara pendapatan usahatani di desa yang direlokasi dengan desa yang tidak direlokasi. Perbedaan tersebut berasal dari perbedaan yang signifkan dalam penerimaan dan biaya. Secara rinci hasilnya dapat dilihat pada Tabel 6.

Tabel 6: Uji Beda Rata-rata Pendapatan per Ha per 14 Bulan

\begin{tabular}{|c|c|c|c|c|c|}
\hline Uraian & Desa & $\mathbf{N}$ & Mean & $\begin{array}{c}\text { Mean } \\
\text { Defference }\end{array}$ & $\begin{array}{c}\text { Sig. } \\
(2- \\
\text { tailed) }\end{array}$ \\
\hline \multirow[t]{2}{*}{ Penerimaan } & Yang Direlokasi & 30 & 104.624 .333 & \multirow{2}{*}{$-252.998 .521$} & \multirow{2}{*}{0,00} \\
\hline & Yang Tidak Direlokasi & 30 & 357.622 .854 & & \\
\hline \multirow[t]{2}{*}{ Biaya } & Yang Direlokasi & 30 & 37.253 .269 & \multirow{2}{*}{$-39.330 .580$} & \multirow{2}{*}{0,00} \\
\hline & Yang Tidak Direlokasi & 30 & 76.583 .840 & & \\
\hline \multirow[t]{3}{*}{ Pendapatan } & Yang Direlokasi & 30 & 67.371 .073 & \multirow{3}{*}{$-213.667 .939$} & \multirow{3}{*}{0,00} \\
\hline & Yang Tidak & 30 & 281.039 .013 & & \\
\hline & Direlokasi & & & & \\
\hline
\end{tabular}


Hasil uji beda rata-rata pada Tabel 6 menunjukkan bahwa terdapat perbedaan penerimaan, biaya, dan pendapatan yang signifikan antara pendapatan petani di desa yang direlokasi dengan yang tidak. Secara rata-rata biaya yang dikeluarkan untuk usahatani di desa yang tidak direlokasi lebih besar dibandingkan dengan desa yang direlokasi. Namun penerimaan yang diterima juga lebih besar karena peningkatan produktivitas dengan penggunaan input yang lebih optimal (Tabel 2). Di samping itu, petani yang tidak direlokasi juga menanam komoditi dengan harga jual yang lebih tinggi (Tabel 1). Hasil uji beda rata-rata berikut menunjukkan perbedaan biaya, penerimaan dan pendapatan yang signifikan tersebut.

Selain itu perbedaan pendapatan disebabkan oleh pemilihan lokasi relokasi yang tidak matang dan terkesan terburu-buru dan tanpa adanya dialog yang melibatkan petani yang lebih arif dan bijak dalam memilih lahan pertanian. sehingga lahan yang telah ditetapkan kurang layak dan tidak mendukung usahatani yang layak juga. Di lihat dari sisi kualitas tanah dan keadaan cuaca. Dan masyarakat belum sepenuhnya fokus dalam pengolahan lahan karena status kepemilikan yang belum jelas, petani masih memiliki rasa ketakutan terhadap lahan tersebut yang sewaktu-waktu bisa saja di ambil kembali oleh pemerintah, kondisi ini sangat mempengaruhi semangat petani dalam berusahatani yang akan berpengaruh terhadap hasil produksi serta produktivitas.

Tabel 6. menunjukkan bahwa pendapatan petani di desa yang tidak direlokasi lebih tinggi dibandingkan dengan pendapatan petani yang direlokasi. Hal ini sesuai dengan hasil kajian Nainggolan et al (2019) yang menunjukkan bahwa terdapat penurunan pendapatan akibat penurunan produktivitas dan peningkatan biaya produksi akibat debu erupsi Gunung Sinabung. Relokasi merupakan salah satu alternatif untuk mengatasi masalah tersebut. Namun hasil kajian ini menunjukkan bahwa alternatif penanganan tersebut perlu memperhatikan kesesuaian lahan di lokasi yang baru serta sarana dan prasarana transpotasi untuk membawa pupuk dan hasil panen. Jika tidak, ketersediaan dan harga pupuk tetap tinggi. Akibatnya penggunaan pupuk tidakoptimal, produktivitas rendah dan biaya produksi tetap tinggi.

Hasil penelitian yang sama juga dinyatakan oleh Simbolon et al (2019) menunjukkan bahwa pendapatan masyarakat yang direlokasi relatif tinggi jika mendapatkan lahan dalam luas yang memadai, serta bantuan dana, pupuk dan bibit yang juga memadai. Kenyataannya, petani yang mendapatakan bantuan-bantuan tersebut masih belum memperoleh pendapatan yang cukup memadai. Penelitian ini menunjukkan bahwa terdapat faktor lain yang menentukan pendapatan tersebut yaitu pemilihan komposisi tanaman. Jenis tanaman harus sesuai dengan kondisi lahan sehingga produktivitas optimum dapat tercapai. Di samping tanaman yang berbeda juga mempunyai harga jual yang berbeda dan kebutuhan tenega kerja dan pupuk yang berbeda. Sehingga pada akhirnya mempengaruhi penerimaan, biaya produksi dan pendapatan petani.

\section{KESIMPULAN}

Pendapatan petani di desa yang di relokasi lebih rendah dibandingakan dengan pendapatan petani di desa yang tidak direlokasi. Oleh karena itu, diharapkan pemerintah dapat memberikan pendampingan kepada petani, sehingga petani bisa memanfaatkan lahan secara optimal melalui pemilihan komoditi yang sesuai. 


\section{Daftar Pustaka}

AAK, (2006). Budidaya Tanaman Bertanam Sayuran di. Kanisius. Yogykarta.

Andrianto, (2014). Pengantar Ilmu Pertanian. Yogyakarta: Global Pustaka.

Badan Pusat Statistik, (2018). Kabupaten Karo Dalam Angka 2018. Badan Pusat Statistik Sumatera Utara.

Balai Penyuluhan Pertanian. Kabupaten Karo. 2019.

Dinas Pertanian Kabupaten Karo, 2018.

Nainggolan, H. L., Ginting, A., Tampubolon, J., Aritonang, J., \& Hutagalung, M. (2019). Dampak erupsi gunung sinanbung terhadap kondisi sosial ekonomi petani hortikultura di Kabupaten Karo, Sosiohumaniora Jurnal Ilmu-Ilmu Sosial dan Humaniora, 21(3), 287-295.

Simbolon, J., Marpaung, P. H. P., Sinaga, R., \& Lestari, G. (2019). Dampak sosial ekonomi pengaruh erupsi sinabung terhadap pendapatan, pendidikan dan kesehatan masyarakat di Kabupaten Karo, Agroteknosains, 3(2), 1-8.

Soekartawi, (2002). Analisis Usahatani. Jakarta: UI Press.

Suratiyah, K. (2011). Ilmu Usahatani. Jakarta: Penebar Swadaya.

Walpole, R. E. (1993). Pengantar Statistika, Jakarta: Gramedia Pustaka Utama. 